\title{
O Leite observado através de diferentes tipologias em unidades de produção familiar no Rio Grande do Sul e suas relações com formas organizativas e inovações tecnológicas*
}

\author{
SAIONARA ARAÚJO WAGNER \\ José Maria Wiest (Orientador - UFRGS) \\ Banca: Isa Beatriz Noll (UFRGS), Carlos Eugênio Daudt (UERGS), Guiomar Pedro Bergmann (UFRGS)
}

Os diferentes tipos de produtores familiares de leite: Moderno ConvencionaL, Em Transição e Tradicional, possuem em suas unidades produtivas atividades diversificadas, o que lhes confere a permanência na atividade, mesmo sendo um dos principais problemas levantados a baixa remuneração da matéria-prima leite. O produtor que está passando do tipo Tradicional para o tipo Moderno Convencional, aqui denominado, Transição, que corresponde a 55\% dos entrevistados, vem realizando investimentos em máquinas e equipamentos de forma coletiva, é um produtor de faixa etária média de 35 anos, fez investimentos em infra-estrutura na última década, diferentemente do tipo Moderno que investiu na atividade na década de 80 e do tipo Tradicional que não o fez, portanto a utilização de diferentes tipologias possibilitou a análise e avaliação de unidades produtivas envolvidas neste estudo, com o objetivo de identificar diferenças no padrão tecnológico, inserção no mercado, organização sistêmica da unidade produtiva, identificação com a racionalidade de produção, aspectos da qualidade de vida e de identidade sócio-profissional entre os diferentes tipos, dentro do mesmo extrato de produtores. A metodologia utilizada baseou-se na revisão de bibliografia, aplicação de questionário semi-estruturado e análise das variáveis que correspondem à problemática proposta. As principais conclusões produzidas por esta pesquisa são as de que a diversificação das atividades, presente em todos os tipos estudados, lhes proporciona a permanência na atividade independentemente do seu grau de tecnificação sendo todos produtores consolidados, o que revela o pluralismo da agricultura familiares de leite no Estado.

Descritores: agricultura familiar, produção familiar de leite, sanidade animal, unidade de produção familiar.

Apresentada: 30 junho 2003

*Tese de Doutorado n. 26 (Especialidade: Medicina Veterinária Preventiva). 134f. Programa de Pós-graduação em Ciências Veterinárias da Faculdade de Veterinária - UFRGS, Porto Alegre/RS. CORRESPONDÊNCIA: S. A. Wagner [saionara-wagner@fepagro.rs.gov.br]. 


\title{
Milk as viewed through different typologies in family producers units in Rio Grande do Sul and its relationships with organizational forms of technological innovations**
}

\author{
SAIONARA ARAÚJO WAGNER \\ José Maria Wiest (Adviser - UFRGS)
}

Committee: Isa Beatriz Noll (UFRGS), Carlos Eugênio Daudt (UERGS), Guiomar Pedro Bergmann (UFRGS)

The different types of dairy family producers: modern conventional, transitional and traditional have varied activities on their farms, that allow them to stay in the dairy production, even when they recognize the low income from traditional to modern conventional ( transitionals, 55\% of the interviewed ones). Are doing investments with machinery and equipments as a group, are around 35 years old and did invested in substructure in the last decade, as opposed by the modern ones, who invested in the dairy activity earlier (80's) and the traditional ones, who did not invested. The use of different typologies allowed the analysis and evaluation of producers units involved in the study, with the aim of identifying differences in technological patterns, market insertion, aspects on quality of life and socio-professional identity among the producers in the same group. The methodology used was based on bibliography, application of a semi-structured questionnaire and analysis of the variables that match the proposed problem. The main conclusions from this study are that the diversification of activities, to proportionate permanence in activity, independent to grade the technological, all the producers are consolidated and reveals the pluralism of the dairy family producers in the region.

Key words: family agriculture, dairy family production, animal health, family production, animal health, family production unit.

\footnotetext{
**Doctoral Dissertation \# 26 (Field: Preventive Veterinary Medicine). 134p. Graduate Program in Veterinary Sciences, Faculdade de Veterinária, Universidade Federal do Rio Grande do Sul ( UFRGS), Porto Alegre/ Brazil. CORRESPONDÊNCIA: S. A. Wagner [ saionara-wagner@fepagro.rs.gov.br
} 